\title{
Sputum sol phase proteins and elastase activity in patients with clinically stable bronchiectasis
}

\author{
Patricia Lloberes, Elena Montserrat, Jose Maria Montserrat, Cesar Picado
}

\begin{abstract}
Background Inflammatory and proteolytic activity occurs in sputum from patients with stable purulent bronchiectasis and has been proposed as the main pathogenetic mechanism of the disease. This study was designed to define further the role of inflammation and proteolysis in bronchiectasis.

Methods Neutrophil elastase activity, sputum concentrations of the serum derived inhibitors $\alpha_{1}$ antiproteinase and $\alpha_{2}$ macroglobulin, and the sputum to serum ratios of albumin and $C$ reactive protein concentration were measured in 26 patients with bronchiectasis.
\end{abstract}

Results Free elastase activity was found in 15 sputum samples. A trend to higher proteolytic and inflammatory activity was found between mucoid and purulent sputum samples, suggesting that inflammatory and proteolytic activities are related to the macroscopic degree of purulence. Purulent sputum had a high sputum to serum ratio of $C$ reactive protein, suggesting local production or active transport of this protein into bronchial secretions. $C$ reactive protein was more sensitive than albumin in detecting a higher degree of inflammation in elastase positive samples.

Conclusion The finding of greater concentrations of $\alpha_{2}$ macroglobulin in purulent and elastase positive samples than in mucopurulent, mucoid and elastase negative sputum samples suggests that this inhibitor may have a role in the proteolysis-antiproteolysis balance in bronchial secretions.

Bronchial secretions have an important role in protecting the epithelium of the respiratory tract. Bronchial mucus may contain proteolytic enzymes as in cystic fibrosis, bronchiectasis, and chronic bronchitis, when it then has the potential to injure the bronchial epithelium. Bacterial colonisation and a persistent inflammatory response in the bronchial tree have been proposed as pathogenetic mechanisms in bronchiectasis. ${ }^{1}$ Polymorphonuclear leucocytes are attracted to sites of inflammation and secrete proteolytic enzymes-for example, neutrophil elastase-and oxygen radicals. ${ }^{2}$ Free neutrophil elastase damages the bronchial epithelium and reduces ciliary function in vitro. ${ }^{34}$ The presence of free elastolytic activity in lung secretions implies a defective inhibition of elastase by its inhibitors, which have been underinvestigated in bronchiectasis. Inflammation in chronic bronchial sepsis has been assessed by the sputum to serum ratio of albumin concentration, ${ }^{56}$ although others have suggested that measurements of $\mathrm{C}$ reactive protein, a simple screening test for active inflammation, might be a useful marker for chronic bronchial sepsis. ${ }^{78}$

To define further the role of inflammation and proteolysis in stable bronchiectasis we measured proteolytic activity in sputum, determined the concentration of the serum derived inhibitors $\alpha_{1}$ antiproteinase and $\alpha_{2}$ macroglobulin in sputum and measured $C$ reactive protein concentration in sputum as a marker of bronchial inflammation.

\section{Patients and methods}

Twenty six outpatients with bronchiectasis were studied during a stable clinical phase of their disease. Diagnosis of bronchiectasis was based on a positive bronchogram or on the daily production of purulent sputum and a chest radiograph suggestive of bronchiectasis. All patients gave informed consent to the study. Sputum was collected over four hours after waking. The macroscopic appearance of sputum was recorded (clear, mucopurulent, or purulent). Sputum was ultracentrifuged at $50000 \mathrm{~g}$ for 90 minutes to separate the sol and gel phases. The sol phase was stored at $-70^{\circ} \mathrm{C}$. During the period of sputum collection $10 \mathrm{ml}$ of venous blood was taken and allowed to clot. The serum was removed after centrifugation and stored at $-70^{\circ} \mathrm{C}$ until analysis.

\section{MEASUREMENT OF ELASTASE ACTIVITY}

The elastolytic activity of the sol phase was measured by an elastin-agarose diffusion plate method. ${ }^{9}$ Samples $(20 \mu \mathrm{l})$ were applied to a well cut in the agarose. The plates were incubated for $\mathbf{4 8}$ hours at room temperature and the zone of elastolysis was measured by using an eyepiece and a graticule. The areas, measured as the square of the diameter of elastolysis, were compared with those produced by known quantities of porcine pancreatic elastase applied to each plate. Sputum elastase activity was expressed in micrograms equivalent to porcine elastase per $100 \mu \mathrm{l}$ of sol phase. The lower limit of measurement was $0.5 \mu \mathrm{g} / 100 \mu \mathrm{l}$. Samples with detectable but not measurable 
Table 1 Protein concentrations and sputum to serum concentration ratios in patients with clinically stable bronchiectasis

\begin{tabular}{lc}
\hline & Median (range) \\
\hline Serum concentration $(\mathrm{mg} / \mathrm{dl}):$ & \\
$\alpha_{1}$ Antiproteinase $(\mathrm{mg} / \mathrm{dl})$ & $243(164-330)$ \\
$\alpha_{2}$ Macroglobulin $(\mathrm{mg} / \mathrm{dl})$ & $221(124-648)$ \\
C reactive protein $(\mathrm{mg} / \mathrm{dl})$ & $0 \cdot 82(0-7 \cdot 5)$ \\
Sputum to serum ratio $\left(\times 10^{-2}\right):$ & $1 \cdot 97(0 \cdot 26-3 \cdot 9)$ \\
Albumin & $4 \cdot 58(0-19 \cdot 9)$ \\
$\alpha_{1}$ Antiproteinase & $2 \cdot 84(0-18 \cdot 6)$ \\
$\alpha_{2}$ Macroglobulin & $269(0-550)$ \\
C reactive protein & \\
Corrected ratio : & $3 \cdot 4(0-9 \cdot 3)$ \\
$\alpha_{1}$ Antiproteinase & $1 \cdot 36(0-24 \cdot 6)$ \\
$\alpha_{2}$ Macroglobulin & $125 \cdot 7(0-577)$ \\
C reactive protein & $2 \cdot 6(0-21 \cdot 5)$ \\
Elastase activity $(\mu \mathrm{g}$ PPE $/ 100 \mu \mathrm{l})$ &
\end{tabular}

^Corrected for sputum to serum albumin ratio.

$\mathrm{PPE}=$ porcine pancreatic elastase.

elastase activity were recorded as zero for statistical purposes.

\section{PROTEIN MEASUREMENTS}

Concentrations of $\mathrm{C}$ reactive protein, albumin, $\alpha_{1}$ antiproteinase, and $\alpha_{2}$ macroglobulin in sputum were measured by radial immunodiffusion (radial immunodiffusion plaques $\mathbf{L}$ and Nor Partigen agarose, with rabbit and sheep antibodies for $\alpha_{1}$ antiproteinase, and rabbit and goat antibodies for $\alpha_{2}$ macroglobulin); lyophilised human plasma proteins were used as standards. Results were expressed in $\mathrm{mg} / \mathrm{dl}$. The same proteins were measured in serum by an immunoelectrophoretic method. The sputum to serum ratio was then calculated for each protein in each sample. Albumin was taken as the reference protein and the sputum to serum ratio for each protein was divided by the sputum to serum ratio for albumin. All ratios were multiplied by $10^{2}$ for convenience. ${ }^{9}$

\section{STATISTICAL ANALYSIS}

The Mann-Whitney $U$ test was used to assess differences between protein concentrations and sputum to serum ratios with respect to the macroscopic appearance of sputum (purulent or mucopurulent) and to the presence of elastase activity. The protein concentrations were expressed as medians (ranges).

\section{Results}

Serum $\alpha_{1}$ antiproteinase and $\alpha_{2}$ macroglobulin concentrations were similar in all patients despite the macroscopic appearance or the presence of elastase activity in sputum. Serum $C$ reactive protein concentration was greater in patients with purulent sputum (median $1.27 \mathrm{mg} / \mathrm{dl}$ (range $0.6-7.5)$ ) than in those with mucopurulent sputum $(0.6(0-0.99)(\mathrm{p}<0.01)$. Tables 1, 2, and 3 summarise the protein concentrations measured in sputum and serum of the patients with bronchiectasis when their clinical state was stable.

\section{ELASTOLYTIC ACTIVITY AND MACROSCOPIC APPEARANCE OF SPUTUM}

The macroscopic appearance of the samples obtained from the 26 patients was purulent in 14, mucopurulent in eight and mucoid in four. Elastolytic activity was detected in 11 of the 14 purulent samples, in four of the eight mucopurulent samples, and in none of the mucoid samples. No differences were observed between purulent and mucopurulent samples with respect to the presence of detectable elastase activity. The median value of elastase activity in the elastase positive samples was $8 \mu \mathrm{g}$ porcine pancreatic elastase/100 $\mu$ l (range $0 \cdot 5-21 \cdot 5)$. The median elastase activity of the purulent samples $(7 \cdot 7(0-21 \cdot 5) \mu \mathrm{g} / 100 \mu \mathrm{l})$ was higher than that of mucopurulent samples $(1 \cdot 3$ $(0 \cdot 5-19 \cdot 5) \mu \mathrm{g} / 100 \mu \mathrm{l})$, but the difference was not significant (table 2 ).

\section{RELATION OF MACROSCOPIC APPEARANCE AND ELASTOLYTIC ACTIVITY TO INFLAMMATORY MARKERS IN SPUTUM}

Sputum to serum ratio of albumin was similar in purulent and mucopurulent samples $(2 \cdot 2$ $(0.33-3.9) \times 10^{-2}$ and $1.4(0.62-3.5) \times 10^{-2}$ $\mathrm{mg} / \mathrm{dl}$ respectively), but it was lower in mucoid samples $\left(0.35(0.26-0.90) \times 10^{-2}\right)$ than in the

Table 2 Protein concentrations and sputum to serum concentration ratios in patients with clinically stable bronchiectasis according to macroscopic appearance of sputum. Values are medians (ranges)

\begin{tabular}{|c|c|c|c|}
\hline & \multicolumn{3}{|l|}{ Sputum } \\
\hline & Purulent & Mucopurulent & Mucoid \\
\hline \multicolumn{4}{|l|}{ Serum concentration $(\mathrm{mg} / \mathrm{dl})$ : } \\
\hline$\alpha_{1}$ Antiproteinase & $251(173-330)$ & $220(164-245)$ & $259(219-328)$ \\
\hline$\alpha_{2}$ Macroglobulin & $227(124-648)$ & $215(149-411)$ & $201(151-223)$ \\
\hline $\mathrm{C}$ reactive protein & $1 \cdot 27(0 \cdot 6-7 \cdot 5) \dagger$ & $0.60(0-0.99) \dagger$ & $0.70(0.64-3.2)$ \\
\hline \multicolumn{4}{|l|}{ Sputum to serum ratio $\left(\times 10^{-2}\right)$ : } \\
\hline Albumin & $2.2(0.3-3.9)$ & $1.4(0.6-3.5)$ & $0.35(0.26-0.9) \dagger$ \\
\hline$\alpha_{1}$ Antiproteinase & $5 \cdot 9(2 \cdot 2-13 \cdot 7)$ & $4 \cdot 6(2 \cdot 3-29 \cdot 9)$ & $0.45(0-3.4) \dagger$ \\
\hline$\alpha_{2}$ Macroglobulin & $3.9(0.46-18.6) \dagger$ & $0.07(0-9.3) \dagger \ddagger$ & $0+$ \\
\hline $\mathrm{C}$ reactive protein & $271(32-544)$ & $328(0-550)$ & $0 \|$ \\
\hline \multicolumn{4}{|l|}{ Corrected ratio*: } \\
\hline$\alpha_{1}$ Antiproteinase & $3.4(0.9-9.3)$ & $3.5(0.9-6.5)$ & $1.5(0-3 \cdot 7)$ \\
\hline$\alpha_{2}$ Macroglobulin & $2 \cdot 06(1 \cdot 1-24 \cdot 6) \ddagger \|$ & $0.05(0-2 \cdot 8)$ & $\mathbf{0}$ \\
\hline $\mathrm{C}$ reactive protein & $126(7 \cdot 8-314)$ & $232(0-577)$ & $0 \|$ \\
\hline Elastase activity $(\mu \mathrm{g}$ PPE $/ 100 \mu \mathrm{l})$ & $7 \cdot 75(0-21 \cdot 5)$ & $1.3(0-19 \cdot 5)$ & $0 \dagger$ \\
\hline
\end{tabular}

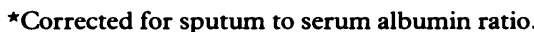

PPE = porcine pancreatic elastase.

$\dagger \mathrm{p}<0.01 ; \ddagger \mathrm{p}<0.05 ; \| \mathrm{p}<0.008$. 
Table 3 Protein concentrations and sputum to serum concentration ratios in patients with clinically stable bronchiectasis according to presence of elastase activity in sputum. Values are medians (ranges)

\begin{tabular}{lcc}
\hline & \multicolumn{1}{l}{ Elastase } \\
\cline { 2 - 3 } & Positive & Negative \\
\hline Serum concentration $(\mathrm{mg} / \mathrm{dl}):$ & & \\
$\alpha_{1}$ Antiproteinase & $245(173-330)$ & $241(164-328)$ \\
$\alpha_{2}$ Macroglobulin & $217(124-648)$ & $223(151-411)$ \\
C reactive protein & $0 \cdot 96(0 \cdot 25-1 \cdot 7)$ & $0 \cdot 7(0-7 \cdot 5)$ \\
Sputum to serum ratio $\left(\times 10^{-2}\right):$ & $2 \cdot 14(0 \cdot 3-3 \cdot 9)$ & $0.93(0 \cdot 26-3)$ \\
Albumin & $4 \cdot 7(2 \cdot 2-13 \cdot 7)$ & $3 \cdot 5(019 \cdot 9)$ \\
$\alpha_{1}$ Antiproteinase & $3 \cdot 52(0-18 \cdot 6) \ddagger$ & $0 \cdot 07(0-9 \cdot 3) \ddagger$ \\
$\alpha_{2}$ Macroglobulin & $328(102-544) \dagger \ddagger$ & $16(0-550) \dagger$ \\
C reactive protein & $3 \cdot 4(0 \cdot 9-9 \cdot 3)$ & $2 \cdot 94(0-3 \cdot 8)$ \\
Corrected ratio*: & $2 \cdot 3(0-2 \cdot 46) \|$ & $0 \cdot 06(0-1 \cdot 6) \|$ \\
$\alpha_{1}$ Antiproteinase & $139(7 \cdot 8-577) \ddagger$ & $6 \cdot 8(0-239) \ddagger$ \\
$\alpha_{2}$ Macroglobulin & $8(0 \cdot 5-21 \cdot 5)$ & 0 \\
C reactive protein & & \\
Elastase activity $(\mu \mathrm{g}$ PPE $/ 100 \mu \mathrm{l})$ & &
\end{tabular}

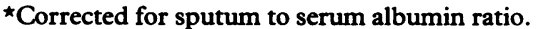

PPE = porcine pancreatic elastic.

$\dagger p<0.08 ; \ddagger p<0.04 ; \| p<0.002$.
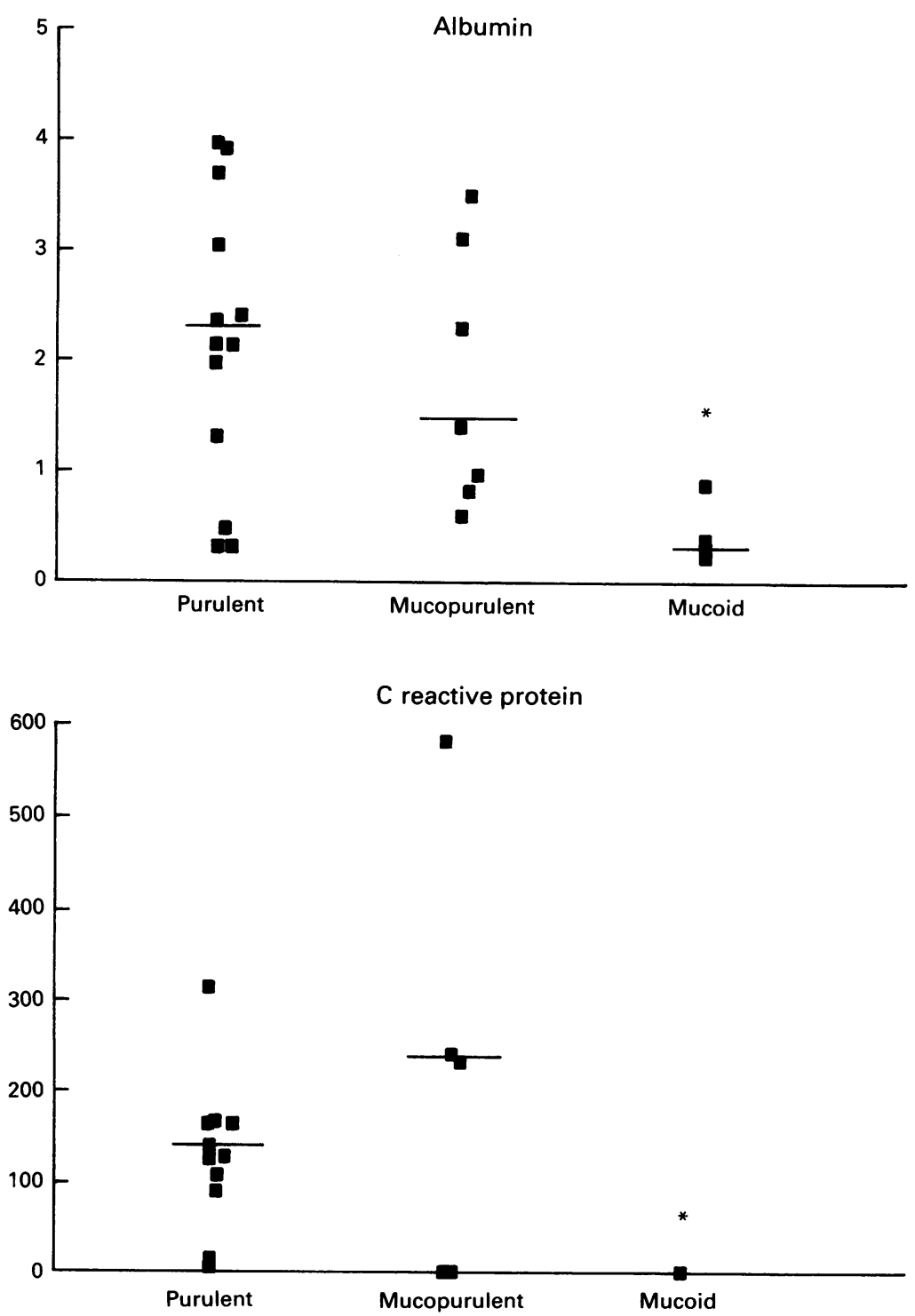

Figure 1 Sputum to serum ratios $\left(\times 10^{-2}\right)$ of $C$ reactive protein and albumin in purulent, mucopurulent, and mucoid sputum samples. The ratio of both proteins was higher in purulent and mucopurulent sputum than in mucoid sputum. (Horizontal bars show median values.) purulent ( $p<0.01$ ) or mucopurulent samples (p < 0.02) (table 2, figure 1). It was similar in elastase positive $\left(2.14(0.33-3.9) \times 10^{-2}\right)$ and elastase negative samples $(0.93(0.26-3) \times$ $\left.10^{-2}\right)$.

Sputum to serum ratio of $C$ reactive protein corrected for albumin was similar in purulent and mucopurulent samples $(126(7.8-314) \times$ $\left.10^{-2}\right)$ and $\left(232(0-577) \times 10^{-2}\right)$ respectively) and was greater in both groups than in mucoid samples when $C$ reactive protein was not detectable (table 2, figure 1). It was greater in elastase positive $\left(139(7 \cdot 8-577) \quad 10^{-2}\right)$ than elastase negative samples $\left(6.8(0-239) \quad 10^{-2}\right.$; $\mathrm{p}<0.03$ ) (table 3, figure 2).

SERUM DERIVED INHIBITORS (table 2 , figure 3 )

$\alpha_{1}$ Antiproteinase The sputum to serum ratio of $\alpha_{1}$ antiproteinase corrected for the albumin ratio was similar in purulent, mucopurulent, and mucoid samples $(3.4(0.9-9.3) \times$ $10^{-2}, 3.5(0.9-6.5) \times 10^{-2}$, and $1.52(0-3.7) \times$ $10^{-2}$ respectively; $\left.\mathrm{p}<0.08\right)$. The ratio corrected for albumin was similar in samples with or without elastase activity $\left(3.4(0.9-9.3) \times 10^{-2}\right.$ and $2.9(0-3.8) \times 10^{-2}$ respectively).

$\alpha_{2}$ Macroglobulin The sputum to serum ratio of $\alpha_{2}$ macroglobulin corrected for albumin was greater $(\mathrm{p}<0.008)$ in purulent samples $(2$ $\left.(1.18-24.6) \times 10^{-2}\right)$ than in mucopurulent $\left(0.05(0-2.8) \times 10^{-2}\right)$ or mucoid samples $(0 ; p<0.002)$. It was greater in elastase positive than in elastase negative samples $(2 \cdot 3$ $(0-24.6) \times 10^{-2}$ and $0.06(0-1.6) \times 10^{-2}$ respectively; $p<0.03$ )

\section{Discussion}

An increased sputum to serum albumin ratio may be a feature of the inflammatory response to infection in the lung. ${ }^{69}$ In our patients this ratio was higher, although not significantly so, in patients with purulent sputum than in those with mucopurulent sputum; it was significantly less in patients with mucoid sputum than in patients with purulent or mucopurulent sputum, suggesting an association between macroscopic purulence and inflammation. The mean values for sputum to serum albumin ratios in our patients were similar to those found in other studies of patients with stable bronchiectasis and cystic fibrosis. ${ }^{569}$ The sputum to serum albumin ratio was also higher, but not significantly so, in patients with elastase positive sputum than in those with elastase negative sputum.

$C$ reactive protein is a pentameric protein synthesised in the liver whose function is unknown, though it may help in removing autogenous and exogenous material from the circulation. This may be its main role in infection, when it acts as a broad spectrum mechanism in recognising products of pathogenetic microorganisms. A raised concentration of this protein is considered to be unequivocal evidence of active tissue destruction, ${ }^{10}$ but this protein has not yet been assessed as an index of active inflammation in bronchiectasis. We measured the serum and sputum concentrations of $\mathrm{C}$ reactive protein in our 

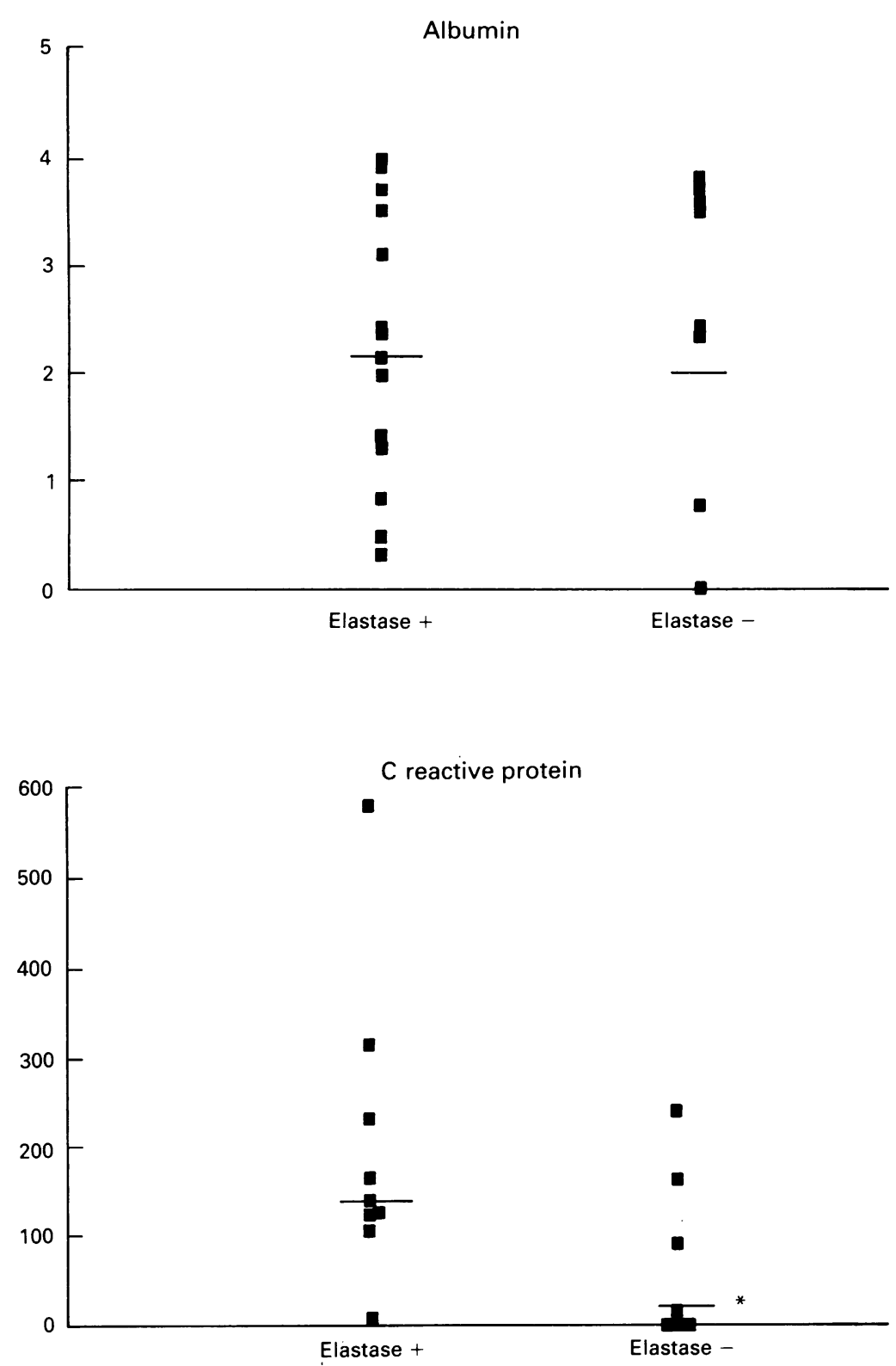

Figure 2 Sputum to serum ratios $\left(\times 10^{-2}\right)$ of albumin and $C$ reactive protein in elastase positive and elastase negative sputum samples. Elastase positive samples showed higher ratios of both proteins, especially $C$ reactive protein $\left({ }^{\star} p<0.03\right)$, when compared with elastase negative samples. Horizontal bars show median values.

patients with bronchiectasis and calculated the sputum to serum ratio, after correcting for the albumin ratio, albumin being used as the reference protein. The ratio for $\mathrm{C}$ reactive protein, corrected for the albumin ratio, was similar in purulent and mucopurulent samples. Interestingly, $\mathrm{C}$ reactive protein was not detectable in any mucoid sample. The high ratio of sputum to serum $\mathrm{C}$ reactive protein corrected for the albumin ratio suggests local production of this protein or a mechanism of active transport from the circulation to the bronchial tree. The high value of the $C$ reactive protein ratio in purulent and mucopurulent sputum from patients with clinically stable bronchiectasis is consistent with the high albumin concentration in the sputum of these patients; $C$ reactive protein is thus another marker of bronchial inflammation in sputum, but it may have other pathogenetic implications in the disease. C reactive protein was also found in significantly greater concentration in elastase positive sputum than in elastase negative sputum, whereas the albumin ratio did not differ significantly in these two groups.

$\alpha_{1}$ Antiproteinase and $\alpha_{2}$ macroglobulin are the main serum antiproteases ${ }^{11}$ in bronchial secretions. They gain entry mainly by passive diffusion from the circulation. This is true for $\alpha_{1}$ antiproteinase, though additional local production of $\alpha_{2}$ macroglobulin by alveolar macrophages may occur. ${ }^{9112}$ Our patients with bronchiectasis showed higher sputum to serum ratios of $\alpha_{1}$ antiproteinase and $\alpha_{2}$ macroglobulin than would be expected by simple diffusion, suggesting some local production for both inhibitors. ${ }^{6}$ Direct evidence of local production for $\alpha_{1}$ antiproteinase does not exist, although alveolar macrophages can synthesise this protein in vitro. Our findings suggest the possibility that both inhibitors are produced locally, although overestimation of $\alpha_{1}$ antiproteinase concentration in the bronchial secretions of patients with cystic fibrosis have been reported with this method of measurement. ${ }^{5}$ Despite these considerations, our finding of a higher ratio of $\alpha_{2}$ macroglobulin in elastase positive and in purulent secretions than in elastase negative, mucopurulent, and mucoid samples suggests a more important role for this inhibitor than has been previously considered. Increased synthesis of $\alpha_{2}$ macroglobulin in compensation for an insufficient antiproteolytic effect of $\alpha_{1}$ antiproteinase in the presence of increased elastolytic activity might account for these findings. The high concentrations of $\alpha_{2}$ macroglobulin can also be attributed to an increased synthesis in lymphoid tissues, due to a chronic inflammatory stimulus in the lung. ${ }^{1314}$ In human bronchiectasis the bronchial wall is the seat of abnormal mononuclear cell infiltration, which suggests the presence of a cell mediated immune reaction. Large numbers of activated $\mathrm{T}$ lymphocytes (many of suppressor/cytotoxic phenotype (OX-8 positive)) are present in the bronchial wall's inflammatory response in experimental bronchiectasis in rats. The high concentrations of $\alpha_{2}$ macroglobulin in sputum may not be an advantage because protease bound to $\alpha_{2}$ macroglobulin retains considerable activity toward elastin precursors such as tropoelastin and might favour proteolysis in the lung. ${ }^{912}$

Our results confirm previous reports suggesting that persistent bronchial inflammation occurs in patients with bronchiectasis producing purulent sputum, even during a stable clinical phase. ${ }^{15} \mathrm{C}$ reactive protein has proved, like albumin, to be a valuable measure of the degree of inflammation in bronchial secretions, although its importance in relation to the pathogenesis of the disease is not clear. Inflammation of the bronchial tree was associated with purulent sputum, the presence of free elastase in sputum, and increased sputum to serum ratios of $\alpha_{1}$ antiproteinase and $\alpha_{2}$ macroglobulin. 

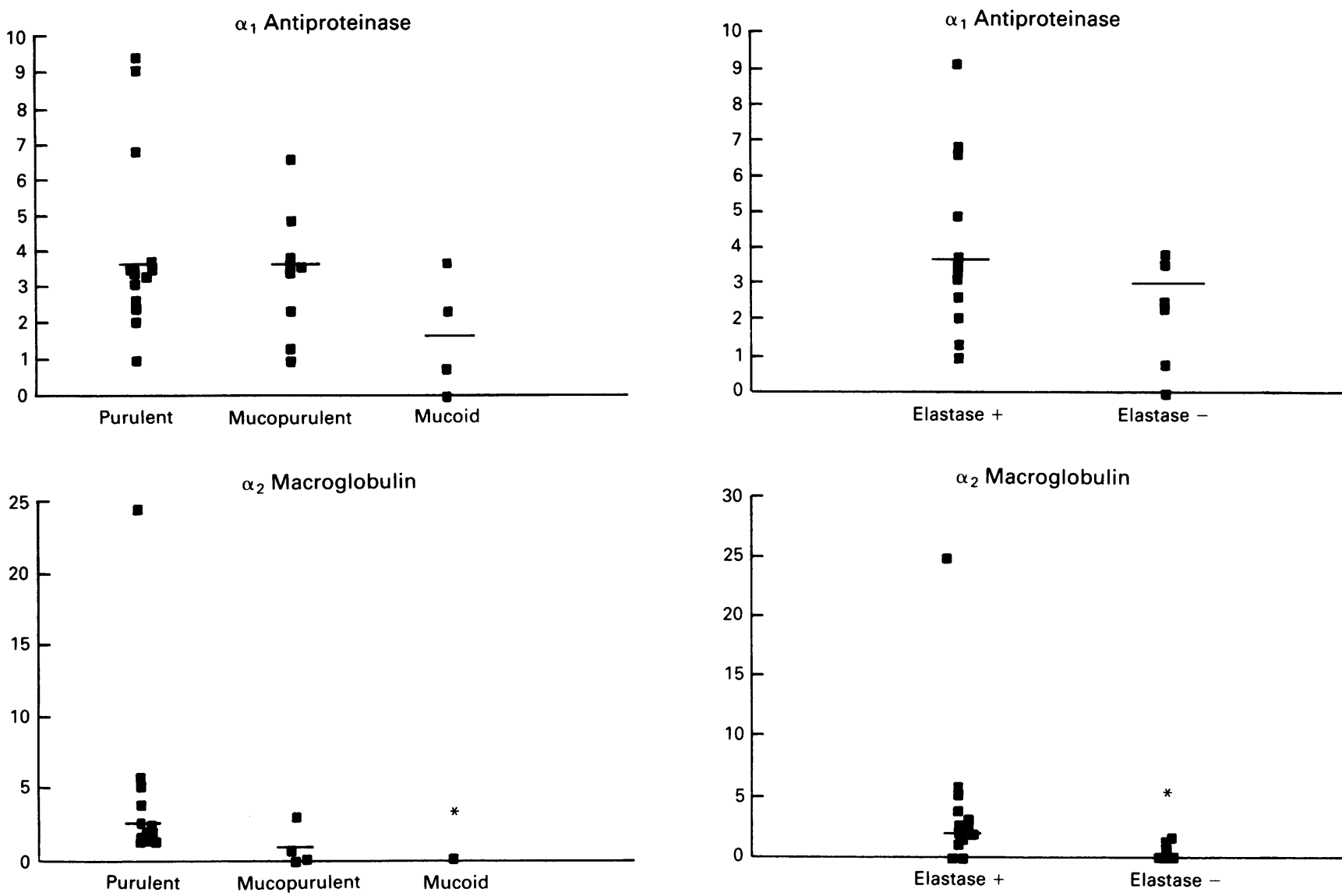

Figure 3 Sputum to serum ratios $\left(\times 10^{-2}\right)$ of serum derived inhibitors according to the macroscopic appearance of sputum and presence of proteolytic activity. Significantly higher ratios of $\alpha_{2}$ macroglobulin were found in purulent and in elastase positive sputum samples than in mucopurulent, mucoid, and elastase negative samples. Horizontal bars show median values.

This study was supported by grant FISS 945/86.

1 Cole PJ. A new look at the pathogenesis and management of persistent bronchial sepsis: a 'vicious circle' hypothesis and its logical therapeutic connotations. In: Davis RJ, ed. Strategies for the management of chronic bronchial sepsis. Oxford: Medicine Publishing Foundation, 1984:1-20.

2 Stockley RA, Hill SI, Morrison HM Starkie CM. Elas tolytic activity of sputum and its relation to purulence and tolytic activity of sputum and its relation to purulence and to lung function

3 Wilson R, Roberts D, Cole PJ. Effect of bacterial products on human ciliary function in vitro. Thorax 1985;40: on hum $125-31$.

4 Brown GM, Donaldson K. Degradation of connective tissue components by lung derived leucocytes in vitro: role of proteases and oxidants.

5 Jackson AH, Hill SL, Afford SC, Stockley RA. Sputum solphase proteins and elastase activity in patients with cystic fibrosis. European Journal of Respiratory Diseases 1984;65:114-24.

6 Stockley RA, Mistry M, Bradwell AR, Burnett D. A study of plasma proteins in the sol phase of sputum from patients with chronic bronchitis. Thorax 1979;34:777-82.
7 Cochrane GM. Chronic bronchial sepsis and progressive lung damage. $B M J$ 1985;29:1026-7.

8 De Beer FC, Nel AE, Gie RP, Donald PR, Strachan AF. Serum amyloid $A$ protein and $C$ reactive protein levels in pulmonary tuberculosis; relation to amyloidosis. Thorax 1984;39:196-200.

9 Stockley RA, Burnett $D$. Serum derived protease inhibitors and leucocyte elastase in sputum and the effect of infection. Bull Eur Physiopathol Respir 1980;16 (suppl):261-71.

10 Pepys MB. C reactive protein fifty years on. Lancet 1981;i:563-7.

11 Stockley RA. Proteolytic enzymes, their inhibitors and lung disease. Clin Sci 1983;64:119-20.

12 Bumett D, Stockley RA. Serum and sputum $\alpha_{2}$ macroglobulin in patients with chronic obstructive lung disease. globulin in patients with chronic obstructive lung disease.

13 Adham NF, Song MK, Eng BF. Hyper $\alpha_{2}$ macroglobulin in narcotic addicts. Ann Intern Med 1978;88:793-5.

14 Lapa e Silva R, Guerreiro D, Noble B, Poulter LW, Cole PJ. Immunopathology of experimental bronchiectasis. Am J Respir Cell Mol Biol 1989;1:297-304.

15 Burnett D, Stockley RA. Serum and sputum $\alpha_{2}$ macroglobulin in patients with chronic obstructive lung disease. Thorax 1981;36:512-6. 